\title{
The use of RFLP analysis in the monitoring of Cercospora beticola strobilurin resistance occurring in sugar beet (Beta vulgaris L.)
}

\section{Wykorzystanie analizy RFLP w monitoringu odporności Cercospora beticola na strobiluryny występującej w buraku cukrowym (Beta vulgaris L.)}

\author{
Agnieszka Kiniec $^{1 *}$, Katarzyna Pieczul ${ }^{2}$, llona Świerczyńska ${ }^{2}$, Jacek Piszczek ${ }^{1}$
}

\section{Summary}

Cercospora leaf spot (CLS) caused by Cercospora beticola is one of the most serious diseases of sugar beet (Beta vulgaris L.). C. beticola has been rapidly developing resistance to commercially used fungicides. In recent years strobilurin has been intensively used to control CLS and this induced an increase of $C$. beticola resistance to this group of fungicides. The aim of the study was to identify sensitive and resistant strains based on the RFLP analysis in plant material collected in different regions in Poland. Application of RFLP technique allowed for quick monitoring of pathogen population, eliminating fungus isolation and time-consuming tests on culture media. The results showed the presence of either sensitive or resistant strains in some regions, mixed strains in others. The obtained results confirmed rapid changes in population structure and increase in the frequency of G143A mutation.

Key words: cercospora leaf spot; Cercospora beticola; strobilurin resistance; G143A

\section{Streszczenie}

Chwościk jest jedną z najpoważniejszych chorób buraka cukrowego. Patogen - Cercospora beticola - w szybkim tempie nabywa odporność na substancje czynne stosowanych fungicydów. W ostatnich latach do ochrony buraka cukrowego intensywnie wykorzystuje się strobiluryny. Spowodowało to z kolei znaczny wzrost odporności $C$. beticola na tę grupę substancji czynnych. Celem badań było oznaczenie na podstawie wyników analizy RFLP obecności szczepów wrażliwych i odpornych w różnych lokalizacjach na terenie Polski, bezpośrednio w materiale roślinnym. Zastosowanie takiej procedury pozwoliło na szybki monitoring populacji patogena, z pominięciem izolacji grzyba oraz czasochłonnych testów na podłożach hodowlanych. Na części z badanych plantacji zidentyfikowano szczepy wrażliwe, a na innych odporne lub populacje mieszane. Uzyskane wyniki potwierdzają szybkie zmiany zachodzące w strukturze populacji patogena i wzrost częstości występowania mutacji G143A.

Słowa kluczowe: chwościk buraka; Cercospora beticola; odporność na strobiluryny; G143A

\footnotetext{
Instytut Ochrony Roślin - Państwowy Instytut Badawczy

Terenowa Stacja Doświadczalna

Pigwowa 16, 87-100 Toruń

${ }^{2}$ Instytut Ochrony Roślin - Państwowy Instytut Badawczy

Władysława Węgorka 20, 60-318 Poznań

*corresponding author: a.kiniec@iorpib.poznan.pl
} 


\section{Wstęp / Introduction}

Cercospora beticola, grzyb powodujący chwościka buraka, jest jednym z najgroźniejszych patogenów buraka cukrowego. Infekcje powodowane przez ten gatunek stanowią problem praktycznie we wszystkich rejonach uprawy na świecie (Holtschulte 2000). Ograniczanie obecności chwościka jest niezwykle istotne, gdyż choroba powoduje znaczną degradację plonów korzeni. Przy optymalnych warunkach rozwoju infekcji straty te moga wynieść nawet 50\% (Shane i Teng 1992). Nasilenie choroby można hamować poprzez odpowiedni płodozmian, głęboką uprawę gleby, eliminację żywicieli wtórnych, czy siew odmian odpornych (Windels i wsp. 1998), jednak głównym narzędziem ochrony buraków przed chwościkiem, niezbędnym do uzyskania wysokiego plonu korzeni pozostają zabiegi chemiczne z zastosowaniem fungicydów (Piszczek 2010).

Sprawca chwościka buraka należy do patogenów szybko nabywających odporność na substancje czynne fungicydów (Bolton i wsp. 2013). Z badań prowadzonych w Terenowej Stacji Doświadczalnej Instytutu Ochrony Roślin - Państwowego Instytut Badawczego w Toruniu wynika, że w latach 2013-2016 odporność C. beticola na strobiluryny (QoI - Quinone Outside Inhibitors) wzrosła od 4,6\% w 2013 do 46,7\% w 2016 roku (dane niepublikowane). Tak drastyczny wzrost odporności grzyba na tę grupę fungicydów ma związek $\mathrm{z}$ intensywnym wykorzystywaniem ich przez rolników (Secor i wsp. 2010). Efektem takich działań może być całkowity brak skuteczności tych substancji czynnych w ochronie plantacji przed chwościkiem. Stwarza to potrzebę szybkiego i wiarygodnego monitoringu.

Strobiluryny łączą się z kompleksem cytochromowym bc1, należącym do III kompleksu oddechowego, przez co hamują procesy oddechowe zachodzące w mitochondriach. Konsekwencją takiego połączenia jest zablokowanie transferu elektronów pomiędzy cytochromem b i c1, w następstwie czego dochodzi do ograniczenia syntezy ATP (adenozynotrójfosforan) i deficytów energetycznych u grzybów (Fernandez-Ortuno i wsp. 2008; Fisher i Meunier 2008). Najistotniejszym źródłem nabywania odporności C. beticola na strobiluryny są mutacje punktowe, powodujące zmianę w sekwencji aminokwasów białka cytochromu b, co osłabia lub całkowicie uniemożliwia przyłączenie fungicydu (Fernandez-Ortuno i wsp. 2008). Wśród mutacji odpowiedzialnych za spadek wrażliwości patogena na wspomnianą wyżej grupę fungicydów wymienia się zamianę w 143 pozycji kodonu glicyny alaniną (G143A), zamianę W 129 pozycji fenyloalaniny leucyną (F129L), czy zamianę glicyny argininą w pozycji 137 (G137R). U większości grzybów odpornych na strobiluryny identyfikowana jest pierwsza z wymienionych mutacji (Fernandez-Ortuno i wsp. 2008; Fisher i Meunier 2008; Bolton i wsp. 2013). Innymi przyczynami powstawania odporności u grzybów są zwiększenie aktywności alternatywnej oksydazy, dzięki czemu dochodzi do obejścia blokowanego cytochromu b, czy działanie transportowych białek błonowych, które zapobiegają gromadzeniu się substancji toksycznych wewnątrz komórek grzybowych (Fernandez-Ortuno i wsp. 2008).
Celem prowadzonych badań było wykonanie testów diagnostycznych, opartych na analizie RFLP (restritction fragment lenght polymorphism), monitorujących występowanie odporności $C$. beticola na strobiluryny (mutacja G143A) w różnych rejonach uprawy buraka cukrowego w Polsce.

\section{Materiały i metody I Materials and methods}

\section{Material}

W pracy wykorzystano liście buraka cukrowego porażone C. beticola, zbierane na terenie województw: wielkopolskiego, lubelskiego, kujawsko-pomorskiego, pomorskiego i łódzkiego (tab. 1). W roku 2016 ocenie poddano liście pochodzące z 16, a w 2017 z 17 lokalizacji. Liście każdorazowo zbierane były w różnych miejscach plantacji, tak aby pobór obejmował swym zasięgiem możliwie dużą część pola.

\section{Izolacja DNA}

Izolację DNA przeprowadzono z losowo wybranych świeżych lub wysuszonych fragmentów liści buraka cukrowego. Każdorazowo wycinano niewielkie fragmenty liści (około 100 fragmentów) zawierające objawy chorobowe wywoływane przez C. beticola, starając się zminimalizować w próbach zawartość tkanki zdrowej. Izolację przeprowadzono przy użyciu zestawu Plant/Fungi DNA isolation Kit (Norgen Biotek), według protokołu producenta. Do izolacji ze świeżych liści użyto $100 \mathrm{mg}$ tkanki, $\mathrm{z}$ liści suchych $-60 \mathrm{mg}$. Materiał roślinny został starannie roztarty w probówkach typu eppendorf $1,5 \mathrm{ml}$ przy użyciu mikrotłuczka. W celu jak najlepszej maceracji materiału do każdej probówki dodano szczyptę sterylnego piasku kwarcowego.

\section{Analiza PCR-RFLP}

W reakcji PCR (polymerase chain reaction) zastosowano startery cytbSF i cyrbSR (Malandrakis i wsp. 2011), zsyntetyzowane przez Genomed S.A., które pozwalają na amplifikację fragmentu genu cytochromu b (cyt b) wielkości około $800 \mathrm{pz}$. Reakcję PCR przeprowadzono w mieszaninie reakcyjnej o końcowej objętości $20 \mu$ l, która zawierała: po $0,3 \mu \mathrm{l} 10 \mathrm{mM}$ starterów, $2 \mu \mathrm{l}$ Dream Tag PCR Bufor (Thermo Fischer Scientific), 0,3 $\mu \mathrm{l}$ dNTP mix (Thermo Fischer Scientific), 0,1 $\mu$ l Dream Taq Polimerase (Thermo Fischer Scientific) oraz $2 \mu \mathrm{l}$ DNA. Zastosowano następujący profil termiczny reakcji PCR: wstępna denaturacja przez 5 min $\mathrm{w} 94^{\circ} \mathrm{C} ; 39$ cykli obejmujących: denaturację $40 \mathrm{~s} \mathrm{w} 95^{\circ} \mathrm{C}$, hybrydyzację starterów $30 \mathrm{~s}$ w $52^{\circ} \mathrm{C}$, elongację $40 \mathrm{~s} \mathrm{w} 72^{\circ} \mathrm{C}$; końcową elongację $-5 \mathrm{~min}$ w $72^{\circ} \mathrm{C}$.

Do trawienia powielonych fragmentów DNA stosowano enzym restrykcyjny AluI. Został on wybrany na podstawie analizy sekwencji genu cytochromu b izolatów C. beticola wrażliwych oraz odpornych na strobiluryny przeprowadzonej w programie NEB cutter2 (http://www. .labtools.us/nebcutter-v2-0/). AluI hydrolizuje DNA wyłącznie $\mathrm{w}$ miejscu sekwencji zasad $5^{\prime}$...AG^CT...3'. Sekwencja zasad GCT jest kodonem alaniny, która u szczepów $C$. be- 
ticola odpornych na strobiluryny zastąpiła glicynę (kodon GGT) w pozycji 143 sekwencji genu cytochromu b.

Mieszanina reakcyjna zawierała $5 \mathrm{ml}$ produktu PCR, $1 \mathrm{ml}$ buforu Cut Smart oraz $1 \mathrm{U}$ enzymu restrykcyjnego AluI (New England Bio Labs). Trawienie prowadzono przez $1 \mathrm{~h} \mathrm{w} 37^{\circ} \mathrm{C}$. Produkty trawienia rozdzielano elektroforetycznie w buforze TBE (Tris-Borate-EDTA), w 2\% żelu agarozowym, barwionym Midori Green stain (Nippon) i analizowano w świetle UV. W wyniku trawienia restrykcyjnego DNA izolatów C. beticola odpornych na strobiluryny obserwowane były fragmenty o wielkościach 473, 171, 144, a w wyniku trawienia DNA szczepów wrażliwych fragmenty o wielkościach 473 i 315 pz.

\section{Wyniki i dyskusja / Results and discussion}

Wzrost odporności grzybów na substancje czynne fungicydów jest jednym $z$ najpoważniejszych problemów pojawiających się w ochronie roślin. Zjawisko to wymaga prowadzenia uważnego oraz szybkiego monitoringu, pozwalającego ocenić strukturę populacji patogena. W niniejszej pracy do oceny występowania mutacji G143A wywołującej odporność na strobiluryny u C. beticola wykorzystana została analiza RFLP. Dotychczas w większości badań opisujących zastosowanie analizy RFLP $\mathrm{w}$ diagnostyce odporności grzybów na fungicydy wykorzystywano DNA uzyskane z czystych kolonii patogena, wyhodowanych na pożywkach (Obuya i Franc 2016). W niniejszej pracy źródłem materiału genetycznego były porażone liście, co pozwoliło na pominięcie izolacji kolonii grzyba $\mathrm{z}$ materiału roślinnego. Zaletą takiego przeprowadzenia analizy RFLP jest nie tylko obniżenie kosztów prowadzonych badań, ale także skrócenie czasu trwania analizy zaledwie do kilku godzin od momentu dostarczenia liści do laboratorium.

Na podstawie przeprowadzonych analiz genetycznych w roku 2016 na większości plantacji $(62,4 \%)$ nie stwierdzono występowania izolatów z mutacją G143A. Szczepy odporne na strobiluryny zidentyfikowano w trzech miejscowościach (18,8\% plantacji), a w kolejnych trzech $(18,8 \%$ plantacji) populacje mieszane, zawierające zarówno izolaty odporne, jak $\mathrm{i}$ wrażliwe. $\mathrm{W}$ próbach zbieranych na terenie województwa lubelskiego oraz pomorskiego szczepy C. beticola odporne oraz wrażliwe na strobiluryny stwierdzono $\mathrm{w}$ podobnych proporcjach. W województwie kujawsko-pomorskim w większości lokalizacji nie zidentyfikowano izolatów $C$. beticola z mutacją G143A warunkującą odporność na strobiluryny. Na plantacjach zlokalizowanych w województwie łódzkim zidentyfikowano wyłącznie izolaty wrażliwe na strobiluryny. W roku 2017 na Lubelszczyźnie nie zdiagnozowano już plantacji zawierających jedynie izolaty C. beticola wrażliwe na strobiluryny. W 2017 roku w Wielkopolsce na połowie badanych plantacji zidentyfikowano obecność izolatów C. beticola z mutacją G143A, jednak tylko na jednej z nich zidentyfikowano wyłącznie szczepy odporne ma strobiluryny (tab. 1). Porównując wyniki analizy materiału pochodzącego $\mathrm{z}$ dwóch lat można stwierdzić, iż udział szczepów wrażliwych na działanie strobiluryn znacznie zmalał - z 62,4\% w 2016 roku do 35,3\% w kolejnym roku. Odsetek populacji wyłącznie odpornych kształtował się na podobnym poziomie, natomiast znacznie wzrosła liczba pól, na których wykryto mieszaniny obydwu szczepów (proporcje DNA izolatów wrażliwych i odpornych były różne) (rys. 1). Uzyskane wyniki mogą być dowodem na szybkie zmiany zachodzące w strukturze populacji patogena i wzrost obecności mutacji G143A warunkującej odporność na strobiluryny. W badaniach prowadzonych na terenie Stanów Zjednoczonych, w latach 2003-2008, przez Secor i wsp. (2010), nie zauważono znaczącego wzrostu odporności izolatów $C$. beticola na strobiluryny. Natomiast w 2013 roku Bolton i wsp. (2013) po raz pierwszy opisali wykrycie mutacji G143A w USA. Jeszcze do 2013 roku mutacja ta nie została odnotowana w Polsce, choć obserwowano wzrost odporności na strobiluryny (Pieczul i Perek 2015). Zaledwie dwa lata później Piszczek i wsp. (2017) zidentyfikowali mutację G143A u izolatów C. beticola pochodzących ze wschodniej Polski.

Przeprowadzone badania pozwalają przypuszczać, że skuteczność strobiluryn $\mathrm{w}$ ochronie buraka przed chwościkiem nadal będzie spadać. Konieczny jest więc dalszy monitoring częstości występowania mutacji G143A w populacji $C$. beticola. Opisana metoda ze względu na niskie koszty oraz proste wykonanie może być stosowana na szeroką skalę do szybkiego monitoringu, czy też oceny zasadności stosowania zabiegów fungicydami zawierającymi strobiluryny. W przypadku obecności w populacji znaczącej liczby izolatów posiadających mutację G143A, takie zabiegi mogą okazać się nieskuteczne.

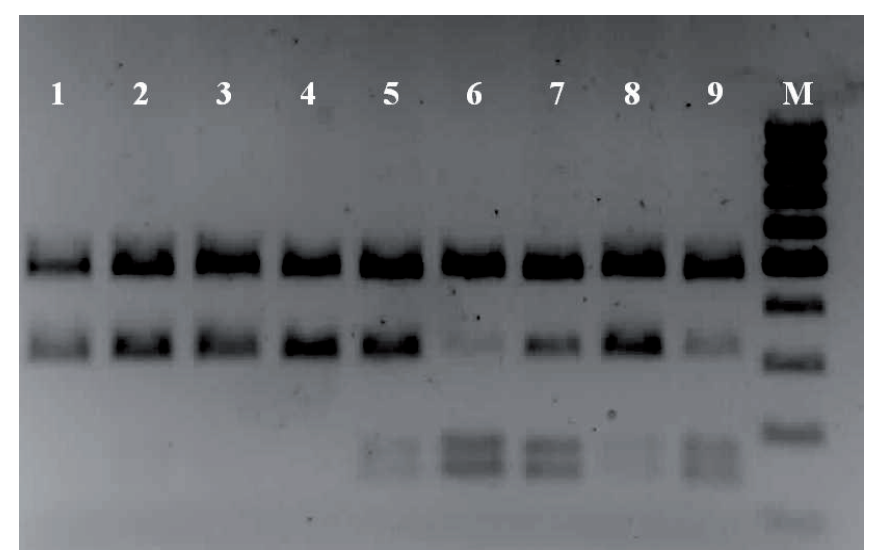

1-4 - próby zawierające DNA izolatów Cercospora beticola wrażliwych na strobiluryny - samples containing DNA of isolates of Cercospora beticola sensitive to strobilurin, 5-9 - próby zawierające DNA izolatów Cercospora beticola wrażliwych i odpornych na strobiluryny w niejednakowych proporcjach $(5,8$ przewaga izolatów wrażliwych, 6, 9 - przewaga izolatów odpornych, 7 - zbliżone proporcje izolatów odpornych i wrażliwych) - samples containing DNA of isolates of Cercospora beticola sensitive and resistant to strobilurin in unequal proportion $(5,8-$ predominance of sensitive isolates, 6, 9 - DNA predominance of resistant isolates, 7 - similar ratios of resistant and susceptible isolates)

M - marker wielkości - size marker

Rys. 1. Analiza polimorfizmu miejsc restrykcyjnych w badanych próbach Cercospora beticola

Fig. 1. Analysis of polymorphic digestion sites of tested strains of Cercospora beticola 
Tabela 1. Badane próby buraka cukrowego oraz oznaczenie szczepów na podstawie analizy RFLP

Table 1. Tested samples of sugar beet and strain assignation by RFLP analysis

\begin{tabular}{|c|c|c|c|c|}
\hline $\begin{array}{l}\text { Numer izolatu } \\
\text { Isolate number }\end{array}$ & $\begin{array}{l}\text { Rok } \\
\text { Year }\end{array}$ & $\begin{array}{l}\text { Województwo } \\
\text { Province }\end{array}$ & $\begin{array}{l}\text { Miejscowość } \\
\text { Locality }\end{array}$ & $\begin{array}{l}\text { Oznaczenie RFLP } \\
\text { RFLP assignation }\end{array}$ \\
\hline $\begin{array}{l}1 \\
2 \\
3 \\
4 \\
5\end{array}$ & \multirow{4}{*}{2016} & $\begin{array}{c}\text { lubelskie } \\
\text { Lublin Voivodeship }\end{array}$ & $\begin{array}{c}\text { Zamostek } \\
\text { Władysławin } \\
\text { Boruń } \\
\text { Stężyca Nadwieprzańska } \\
\text { Trzeszkowice }\end{array}$ & $\begin{array}{c}\text { wrażliwy - sensitive } \\
\text { odporny - resistant } \\
\text { mieszany - mixed } \\
\text { odporny - resistant } \\
\text { wrażliwy - sensitive }\end{array}$ \\
\hline $\begin{array}{l}6 \\
7 \\
8 \\
9\end{array}$ & & $\begin{array}{l}\text { kujawsko-pomorskie } \\
\text { Kujawsko-Pomorskie } \\
\text { Voivodeship }\end{array}$ & $\begin{array}{l}\text { Chodeczek } \\
\text { Kamienna } \\
\text { Królikowo } \\
\text { Suchary }\end{array}$ & $\begin{array}{l}\text { wrażliwy - sensitive } \\
\text { wrażliwy - sensitive } \\
\text { mieszany - mixed } \\
\text { wrażliwy - sensitive }\end{array}$ \\
\hline $\begin{array}{l}10 \\
11 \\
12 \\
13\end{array}$ & & $\begin{array}{c}\text { pomorskie } \\
\text { Pomeranian Voivodeship }\end{array}$ & $\begin{array}{c}\text { Suchy Dąb } \\
\text { Trępnowy } \\
\text { Gniewskie Pole } \\
\text { Gurcz }\end{array}$ & $\begin{array}{l}\text { wrażliwy - sensitive } \\
\text { mieszany - mixed } \\
\text { odporny - resistant } \\
\text { wrażliwy - sensitive }\end{array}$ \\
\hline $\begin{array}{l}14 \\
15 \\
16 \\
\end{array}$ & & $\begin{array}{l}\text { łódzkie } \\
\text { Łódź Voivodeship }\end{array}$ & $\begin{array}{c}\text { Ostrowy } \\
\text { Kajew } \\
\text { Siedlec } \\
\end{array}$ & $\begin{array}{l}\text { wrażliwy - sensitive } \\
\text { wrażliwy - sensitive } \\
\text { wrażliwy - sensitive }\end{array}$ \\
\hline $\begin{array}{l}17 \\
18 \\
19\end{array}$ & \multirow[b]{2}{*}{2017} & $\begin{array}{c}\text { lubelskie } \\
\text { Lublin Voivodeship }\end{array}$ & $\begin{array}{c}\text { Zakręcie } \\
\text { Stężyca } \\
\text { Masłomęcz }\end{array}$ & $\begin{array}{c}\text { mieszany - mixed } \\
\text { odporny - resistant } \\
\text { mieszany - mixed }\end{array}$ \\
\hline $\begin{array}{l}20 \\
21 \\
22 \\
23 \\
24 \\
25 \\
26 \\
27 \\
28 \\
29 \\
30 \\
31 \\
32 \\
33 \\
\end{array}$ & & $\begin{array}{c}\text { wielkopolskie } \\
\text { Wielkopolska Voivodeship }\end{array}$ & $\begin{array}{c}\text { Dopiewiec } \\
\text { Zamysłowo } \\
\text { Witobel } \\
\text { Wrąbczyn } \\
\text { Trzcielin } \\
\text { Ponin } \\
\text { Lubiechowo } \\
\text { Kowalewo } \\
\text { Granowo } \\
\text { Gnin } \\
\text { Kamieniec } \\
\text { Parzęczewo } \\
\text { Ptaszkowo } \\
\text { Ruchocice }\end{array}$ & $\begin{array}{c}\text { wrażliwy - sensitive } \\
\text { wrażliwy - sensitive } \\
\text { mieszany - mixed } \\
\text { mieszany - mixed } \\
\text { wrażliwy - sensitive } \\
\text { mieszany - mixed } \\
\text { wrażliwy - sensitive } \\
\text { mieszany - mixed } \\
\text { mieszany - mixed } \\
\text { mieszany - mixed } \\
\text { wrażliwy - sensitive } \\
\text { wrażliwy - sensitive } \\
\text { odporny - resistant } \\
\text { mieszany - mixed }\end{array}$ \\
\hline
\end{tabular}

\section{Wnioski / Conclusions}

1. Opisany protokół diagnostyczny może być wykorzystywany do szybkiego monitoringu populacji patogena bezpośrednio $\mathrm{w}$ materiale roślinnym, $\mathrm{z}$ pominięciem izolacji kolonii C. beticola.
2. Struktura populacji C. beticola na terenie Polski podlega szybkim, niekorzystnym zmianom - obserwowany jest gwałtowny wzrost występowania izolatów $\mathrm{z}$ mutacją G143A, warunkującą odporność na strobiluryny.

\section{Literatura / References}

Bolton M.D., Riviera V., Secor G. 2013. Identification of the G143A mutation associated with QoI resistance in Cercospora beticola field isolates from Michigan. Pest Management Science 69 (1): 35-39. DOI: 10.1002/ps.3358.

Fernandez-Ortuno D., Tores J.A., de Vicente A., Perez-Garcia A. 2008. Mechanism of resistance to QoI fungicides in phytopathogenic fungi. International Microbiology 11 (1): 1-9. DOI: 10.2436/20.1501.01.38.

Fisher N., Meunier B. 2008. Molecular basis of resistance to cytochrome bc1 inhibitor. FEMS Yeast Research 8 (2): $183-192$. DOI:10.1111/j.1567-1364.2007.00328.x. 
Holtschulte B. 2000. Cercospora beticola - worldwide distribution and incidence. Advances Sugar Beet Research International Institute for Beet Research 2: 5-16, ref. 20.

Malandrakis A., Markoglou A., Nikou D., Vontas J., Ziogas B. 2011. Molecular diagnostic for detecting the cytochrome b G143S - Qol resistance mutation in Cercospora beticola. Pesticide Biochemistry and Physiology 100 (1): 87-92. DOI: 10.1016/j.pestbp. .2011.02.011.

Obuya J.O., Franc G.D. 2016. Molecular analysis of Cercospora beticola isolates for strobilurin resistance from the Central High Plains, USA. European Journal of Plant Pathology 146 (4): 817-827. DOI: 10.1007/s10658-016-0959-x.

Pieczul K., Perek A. 2015. Przyczyny odporności izolatów Cercospora beticola (chwościk buraka) na strobiluryny w Wielkopolsce. [The reasons of strobilurin resistance Cercospora beticola (cercospora leaf spot) isolates in Wielkopolska region]. Progress in Plant Protection/Postępy w Ochronie Roślin 55 (1): 45-48. DOI: 10.14199/ppp-2015-008.

Piszczek J. 2010. Epidemiologia chwościka buraka cukrowego (Cercospora beticola) w centralnej Polsce. Rozprawy Naukowe Instytutu Ochrony Roślin - Państwowego Instytutu Badawczego, Zeszyt 23, 70 ss.

Piszczek J., Pieczul K., Kiniec A. 2017. First report of G143A strobilurin resistance in Cercospora beticola in sugar beet (Beta vulgaris) in Poland. Journal of Plant Diseases and Protection. DOI: 10.1007/s41348-017-0119-3.

Secor G.A., Rivera V.V., Khan M.F.R., Gudmestad N.C. 2010. Monitoring fungicide sensitivity of Cercospora beticola of sugar beet for disease management decisions. Journal of Plant Diseases and Protection 94 (11): 1272-1282. DOI: 10.1094/PDIS-07-09-0471.

Shane W.W., Teng P.S. 1992. Impact of Cercospora leaf spot on root weight, sugar yield and purity of Beta vulgaris. Plant Disease 76 (8): 812-820. DOI: 10.1094/PD-76-0812.

Windels C.E., Lamey H.A., Hilde D., Widner J., Knudsen T. 1998. A Cercospora leaf spot model for sugar beet: In practice by an industry. Plant Disease 82 (7): 716-726. 